\title{
Complicación malla obturatriz
}

\author{
Puyol Pallás M, Nur Y, Campos R, Otero Xanco J, Gómez Parada J, Ros Valverdú R. \\ Unidad Suelo Pélvico. Hospital Sant Juan de Deu. Martorell.
}

\section{$\mathrm{P}$} resentamos el caso clínico de rechazo de una malla de polipropileno, empleada como tratamiento primario en una paciente con incontinencia urinaria de esfuerzo por hipermovilidad uretral, vía transobturatriz.

Paciente de 48 años, secundípara, diagnosticada de IU de esfuerzo genuina de intensidad grave, a quien se realiza una plastía anticontinencia mediante una banda suburetral de polipropileno (Optape, Mentor-Porges) libre de tensión, sin complicaciones quirúrgicas y con un resultado satisfactorio en términos de continencia urinaria en la visita realizada al mes de la cirugía.

A los tres meses consulta por la presencia de leucorrea maloliente y amarillenta, junto con dispareunia. A la exploración fisica se detecta una banda extruida a través de un ojal vaginal en la zona suburetral media izquierda. Se recorta la malla extruida unos dos centímetros, iniciando tratamiento local con estrógenos y antibiótico anaerobicida.

Al mes ha desaparecido la dispareunia, pero persiste la leucorrea maloliente. A la exploración fisica no se aprecia la malla extruida. Pensando que la causa de la leucorrea era el DIU, se procede a la retirada del mismo.

En el nuevo control, al mes, persiste la leucorrea, asociándose dolor en zona perianal y obturatriz izquierda. A la exploración fisica se aprecia una zona indurada flogótica, con drenaje de material purulento a nivel perianal izquierdo, a sí mismo existe una zona indurada a nivel de fosa obturatriz izquierda. Por vagina, en el antigua ojal de la malla recortada, drena material purulento.

Ante estos hallazgos se decide la revisión quirúrgica. Encontrando un trayecto fistuloso que comunica el orificio obturatriz con la región perineal. Asímismo existe una comunicación entre vagina y orificio transoburatriz.

Se opta por poner todo a plano, extrayendo el resto de la malla izquierda y colocando un tutor entre zona perineal y zona obturatriz (Fig. 1).

A los dos meses la curación es total (Figs. 2 y 3).

La paciente sigue continente a pesar de todo.

Correspondencia autor: Dr. M. Puyol Pallás

Unidad Suelo Pélvico. Hospital Sant Juan de Deu. Martorell.

E-mail autor: 21789mpp@comb.es

Información artículo: Imágenes en Urología

Trabajo recibido: septiembre 2006

Trabajo aceptado: octubre 2006

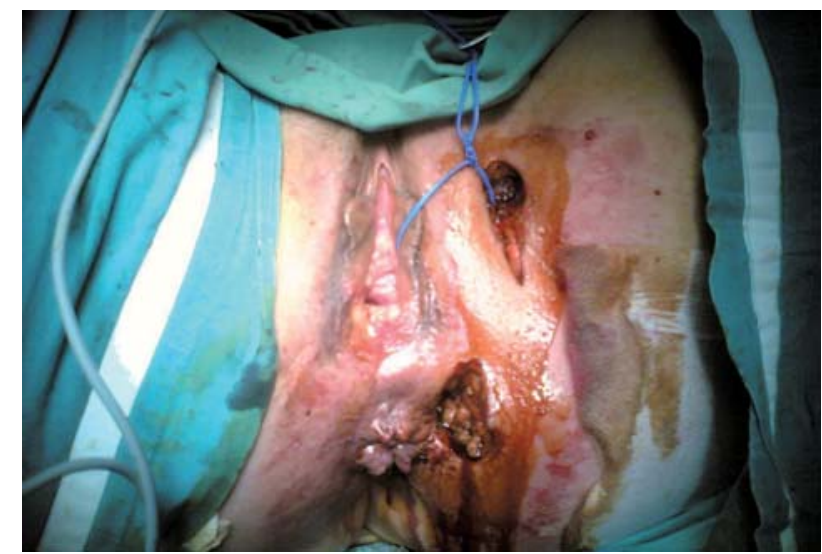

FIGURA 1

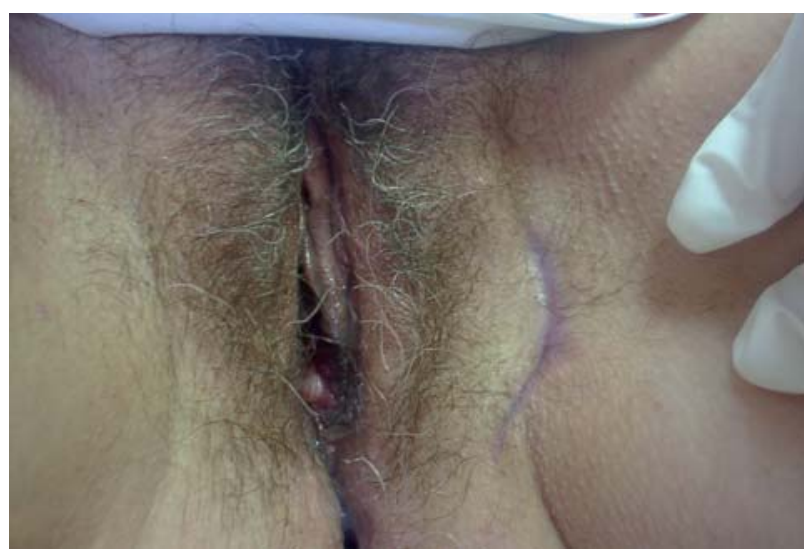

FIGURA 2

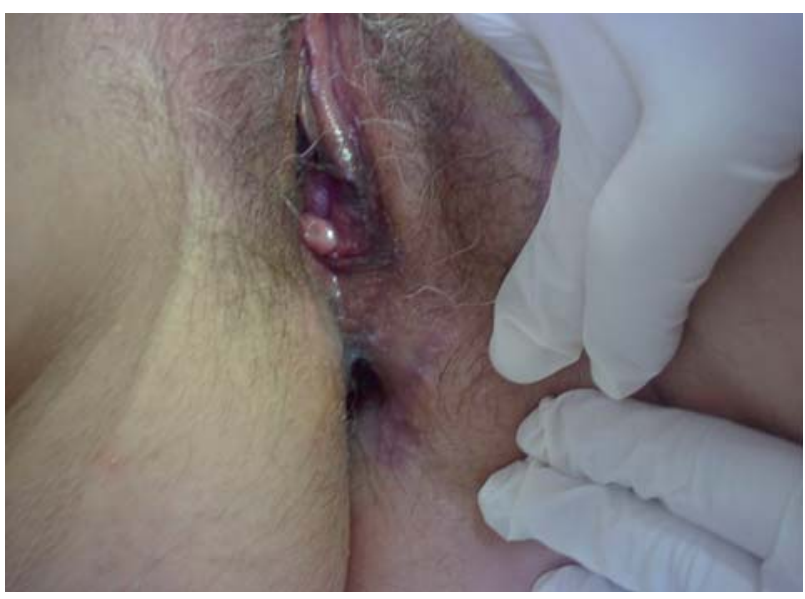

FIGURA 3 